\title{
Training of Critical Thinking Skills in Teacher Candidates and Placebo Effect: A Quasi-Experimental Study ${ }^{1}$
}

\author{
Betul DEMIRBAG* \\ Ali UNISEN** \\ Abdullah YESILYURT ${ }^{* * *}$
}

\section{Suggested Citation:}

Demirbag, B., Unisen, A., \& Yesilyurt, A. (2016) Training of critical thinking skills in teacher candidates and placebo effect: A quasi experimental study. Eurasian Journal of Educational Research, 63, 375-392 http://dx.doi.org/ 10.14689/ejer.2016.63.21

\begin{abstract}
Problem Statement: In recent years many different studies have examined critical thinking disposition; however, these studies focus on investigating the variables that are related to this subject. There are actually few empirical studies in the literature. It is clear that there is a need for experimental research in order to comprehend the process of critical thinking in-depth.

Purpose of the Study: This study investigates the contrastive effect of an experimental program and the placebo effect on the improvement of critical thinking disposition of university students.

Method: Sixty-three participants from the students of Arabic Language Education in the Faculty of Education in Adiyaman University were divided into three classes as experiment, placebo, and control groups, each of which consisted of 21 participants. As the placement was on an already existing class system, the study was conducted using a quasi-experimental design. In the experiment group, an eight-week program, which was developed by researchers, was applied. The study was carried out in the last 10 to 15 minutes of Educational Psychology lessons. In the placebo group a positive atmosphere was provided in the class and the students were motivated toward critical thinking by being informed about the necessities of it, and in the control group no applications were used. California Critical Thinking Disposition Inventory, which was adapted
\end{abstract}

\footnotetext{
${ }^{1}$ This study was presented at the $2^{\text {nd }}$ International Eurasian Educational Congress in Ankara, 810 June, 2015

*Corresponding author: Res. Asst. Gazi University, demirbagbetul@gmail.com

** Dr. Adiyaman University, aliunisen@gmail.com

${ }^{* * *}$ Res. Asst. Gazi University, yesilyurtabdullah@yahoo.com.tr
} 
into Turkish by Kokdemir in 2003, was used to assess the critical thinking skills of the participants. SPSS 20.0 was used to analyze data. Variance analysis, independent samples $t$-test and Ancova analysis were used to examine the data.

Findings and Results: Independent samples $t$-test results pointed out that there was not a significant difference between male and female participants. Variance analysis conducted for age variables produced no significant difference between the groups. It was found that the highest improvement in critical thinking disposition of teacher candidates was observed in the placebo group, and the experimental group ranked second; however, Ancova analysis showed that there were no significant differences between the experiment, the placebo and the control groups' posttests.

Conclusion and Recommendations: Age, gender, and groups of the student were observed as not being significant variables in critical thinking disposition at the end of the study. Within the study, it is an important finding that merely the effort for creating a positive atmosphere in the placebo group induces a better level of improvement than the experiment group where activity and practice were made possible. Findings were discussed based on the relevant literature.

Keywords: Thinking, critical thinking, placebo effect, teacher candidates

\section{Introduction}

Thinking is an important concept that has been hugely emphasized since ancient times. It can briefly be described as asking reasonable questions to oneself in order to solve an encountered problem by means of existing experiences and background. The process involves mental processes such as problem solving, inquiring, reflecting upon and criticizing an event, all of which depend on forming meaningful connections between concepts and events and drawing conclusions (Aksoy, 2003, p. 83). Critical thinking, on the other hand, is a concept used since 1930s, but its origin dates back as early as the period of Socrates (Kokdemir, 2003, p. 42) and can be described as "the ability to view, interpret and decide on issues with a doubt-based inquiry approach" (Bagci and Sahbaz, 2012, p.1) The roles and functions of higher education programs, which are the institutions taking the most comprehensive steps oriented toward improving critical thinking skills, in that process are disputable. In this context, the main point of departure should be the question: "Is the duty of universities providing the students with the correct answers or ensuring that they ask the correct questions" (Karakas, 2014). In this study, a program on improving critical thinking skills was tested on teacher candidates in a quasi-experimental setting.

Critical thinking is not the only responsibility of higher education institutions, which serve as bridges for presenting science, novelties, ideas, and applications to 
the public/large masses, to graduate individuals equipped with knowledge, and to prepare them for their chosen field. Universities undertake important missions in shaping societies and creating future plans. One such mission is to equip individuals that are supposed to take on duties in various social statuses with the intellectual skills to prepare them for their positions (Aybek, 2007, p. 44; Seferoglu \& Akbiyik, 2006, p. 193). Additionally, the university is the formal educational stage where the teacher mediates between the learner and source of information as a third element for the last time and is expected to make him or herself completely redundant in the end.

The fact that teacher candidates do not possess critical thinking skills affects their problem solving skills adversely, which, in turn, inactivates the teachers in organizing learning experiences. Thus, the rhetoric on ideals of raising a generation capable of thinking, inquiring and deciding is not put into effect. Then, to what extent do the existing educational systems allow for the establishment of critical thinking in teacher training?

Definitions are the core of science. Reaching a minimum agreement on definitions, especially in studies that are to be carried out in social sciences, is an important prerequisite to producing a qualified piece of work in accumulative science. Seferoglu and Akbiyik (2006, p. 199) point out that although critical thinking has been recently used with the same meaning as high-level cognitive skills, the correct definition should be "logical and reflective thinking focused on deciding on what to do and what to believe." In this context, the purpose of studies on improving critical thinking is to construct a thinking process that will allow output production consistent with logic.

It has been observed in international literature that studies on helping acquire critical thinking, which is accepted as a "teachable process" (Cohen, 1993), are mainly successful. Kokdemir (2003, p. 49) indicated that a study in the USA analyzing the effectiveness of psychology classes showed that only that subject by itself triggered critical thinking, whereas the sociology class did not create a similar effect. A recent study by Adam and Manson (2014) pointed out that students' critical thinking skills can be improved without applying difficult methods, but just through thinking on pseudoscience scenarios.

Critical thinking disposition is expected to be independent of gender, and many findings in international literature support this expectation (Bagci and Sahbaz, 2012; Korkmaz, 2009a; Emir, 2012; Coskun, 2013; Karadeniz and Gursoy, 2014). However, there are also some other researches with contrary results (Kartal, 2012; Alkin Sahin, Tunca and Ulubey, 2014). Moreover, it is known that critical thinking promotes academic writing disposition (Bayat, 2014) and that micro-education has a positive effect on critical thinking (Arsal, 2015). When studies about critical thinking levels are examined, there are some that point out that teacher candidates studying in various universities and teachers on the job in our country have high levels of critical thinking (Hamurcu, Gunay, \& Akamca, 2005). However, it has been shown that the number of such studies are quite limited. Findings of studies demonstrate that 
teachers and candidates generally have average or low levels of critical thinking (Korkmaz, 2009a, p. 879; Coskun, 2013, p. 143; Korkmaz, 2009b, p. 1; Ulucan, Turkcapar, \& Cihan, 2011, p. 42; Sengul \& Ustundag, 2009, p. 237). The researchers attribute such results to the fact that teaching methods encourage memorization and that courses are evaluated not by means of questions allowing students to employ their metacognitive skills, but by questions evaluating their levels of information and comprehension.

When related researches are analyzed, although it is said that memorization and teaching methods practiced in classes account for the low and average levels of critical thinking in higher education institutions in our country, it is apparent that the number of experimental studies to support this correlation is quite few. Polat (2015), who made a content analysis on studies in Turkey about critical thinking skills, emphasized this shortage and remarked on the need for more experimental and mixed-method studies. In light of these findings, it is clear that updated empirical findings related to the subject are needed. Additionally, none of these studies took into account the placebo effect while assessing the effect of employed methods and programs on critical thinking. Yet, the point agreed upon by all conceptions related to critical thinking is that it encourages the individual to ask questions and calls out cognitive skills. That means, the relevance of the subject to the course or the existence/absence of a critical thinking program is considered to be of secondary importance and encouraging thinking is thought to be of top priority.

The purpose of this study is to assess a structured program in a class atmosphere that allows students to express their ideas freely with this fact being clearly emphasized in the class in improving the critical thinking skills of teacher candidates. The following sub-hypotheses were tested for this aim:

a. There is no significant difference in critical thinking disposition of the participants based on gender.

b. There is no significant difference in critical thinking disposition of the participants based on age.

c. There is no significant difference between the pretest mean scores of experiment, placebo, and control groups.

d. There are significant differences between the posttest scores of experiment, placebo, and control groups in favor of the experiment and placebo groups when the pretest scores are taken under consideration.

\section{Method}

\section{Research Design}

Since the aim of this study is to observe the change created by a critical thinking education program and the placebo effect upon teacher candidates, the most appropriate method is an experimental one. It is necessary in experimental circumstances to control all kinds of mediating variables affecting the dependent variable and to isolate the experiment of those possible effects. However, by its 
nature, social science has a structure which does not allow all variables to be properly taken under control; thus, in this study as well, the choice of participants for the experiment, placebo, and control groups was made spontaneously as there was an previously existing class environment. Hence, it would be appropriate to call this study a "quasi-experimental method" in consideration of the relevant literature.

\section{Research Sample}

The population of the study includes all of the students studying at faculties of education in Turkey and the samples consist of the freshman students of Arabic Language Education in Adiyaman University during the 2014/2015 academic year. As the students in the study were just the limited number of students registered in the program, it was not possible to apply random sampling or sampling based on volunteering. Nevertheless, in order to minimize potential noisy effects that may be caused by the affinity between critical thinking and academic success, which is underlined in the literature (Korkmaz, 2009a; Tumkaya, 2011), a balanced distribution among the groups was considered using a systematic method of assignment considering the last digits of student numbers that are given according to the university entrance scores of students. There were a total of 63 participants in experiment, placebo, and control groups, each one consisting of 21 students. Demographic information about the participants is given in Table 1.

Table 1.

Demographic Information about the Participants

\begin{tabular}{lccc}
\hline & Group & $N$ & $\%$ \\
\hline \multirow{3}{*}{ Gender } & Female & 48 & 76.2 \\
& Male & 15 & 23.8 \\
& Total & 63 & 100 \\
\hline \multirow{3}{*}{ Age } & 18 & 11 & 17.5 \\
& 19 & 19 & 30.2 \\
& 20 & 17 & 27 \\
& $21+$ & 16 & 25.4 \\
\hline
\end{tabular}

Table 1 shows the range of participants in terms of gender and age. The participants display a balanced distribution in terms of age, whereas the tendency is mainly toward female, which can be accepted as a projection of the fact that the female population outweighs the male students in foreign language education institutions in higher education in our country. 


\section{Research Instruments and Procedure}

Since the effects of two separate processes, critical thinking skills improvement program and placebo effect, are intended to be investigated in this study, a pretest/posttest controlled group design of quasi-experimental method was planned and an experiment group, a placebo group, and a control group were formed. The study took place in the scope of the Education Psychology course. The experiment group was given critical thinking skills exercises created by the researchers before the beginning of the academic term. The application was repeated for eight weeks, sparing the last ten/fifteen minutes of the class for activities. The aim during the activities was to have the students suggest solutions for or express their ideas about a question/situation directed to them that might have more than one answer. After the answer of the first student, the others are expected to negate it and explain their own evidence. The process ended after statements of the students divided into various groups of opinions were summarized.

The route taken with the placebo group during the study is described as follows: students in the placebo group were orally motivated for critical thinking in the general course of the lecture-not under constraints of a specific period. This motivation was provided through statements of encouragement such as "critical thinking is important," "try changing your perspective," and "break your taboos and get the big picture" during the lecture. But the students were not provided with an opportunity to practice critical thinking activity, nor were they confronted with a question or everyday situation that they could apply to this kind of thinking strategy. No manipulations were made on the control group. The study took eight weeks.

For the assessment of critical thinking skills, the California Critical Thinking Disposition Inventory (CCTDI), a six-point Likert-type scale adapted into Turkish by Kokdemir, was used. The scale consists of 6 dimensions and 51 items. The validity and reliability values of CCTDI found for university students by Kokdemir (2003) were .88 and .86 , respectively without evaluating the sub-dimensions separately in detecting critical thinking. The reliability coefficient of CCTDI in this study was .70.

\section{Data Analysis}

In this study, the data were collected on two different dates. A pretest was applied on all students of Arabic Language Education that would be taking the Educational Psychology course at the beginning of the term. Then, the participants were divided into experiment, placebo, and control groups based on the last digits of their student numbers. At the end of the eight-week period, all of the participants were asked to fill in the CCTDI scale again, which was registered as the posttest.

The data uploaded onto electronic media were analyzed using the SPSS software program. In the analysis, $t$ test for independent groups, variance analysis, covariance analysis and for reliability evaluation Cranach Alpha were used. 


\section{Results}

Findings gathered as a result of statistical operations in order to reach subhypotheses of the study and the related tables are provided in this section.

\section{The First Sub-Hypothesis: Findings Regarding the Gender Variable}

Table 2 summarizes the results of the $t$ test for independent samples carried out in order to test the argument that there is no significant difference in critical thinking disposition total scores of the participants based on gender, stated in the first subhypothesis.

\section{Table 2.}

Total Scores for Critical Thinking Based on Gender

\begin{tabular}{llllll}
\hline & $N$ & $\bar{X}$ & $S S$ & $F$ & $p$ \\
\hline Female & 48 & 222,11 & 19,38 & .284 & .34 \\
Male & 15 & 223,83 & 21,34 & & \\
\hline
\end{tabular}

Table 2 indicates a difference between the mean scores of female participants $(\bar{X}=222,11)$ and male participants $(\bar{X}=223,83)$ in favor of the male but that difference is not a significant one at the level of $\mathrm{p}<.05$. Thus, it can be said that there is not a difference in critical thinking in terms of gender.

The Second Sub-Hypothesis: Findings Regarding the Age Variable

The second sub-hypothesis of the study is "There is no significant difference in critical thinking disposition of the participants based on age." In order to test this hypothesis, age groups that were converted to artificial truncated variables were compared in terms of critical thinking disposition mean scores. After the assumption of homogeneity of variances was met, one-way Anova analysis was carried out. The results are given in Table 3. 
Table 3.

Critical Thinking Disposition Scores Based on Age

\begin{tabular}{cccccc}
\hline & $N$ & $\bar{X}$ & $S S$ & $F$ & $p$ \\
\hline 18 & 11 & 223,87 & 17,71 & & \\
19 & 19 & 217,04 & 25,02 & & \\
20 & 17 & 219,90 & 15,04 & 1,614 & .196 \\
$21+$ & 16 & 230,88 & 16,75 & & \\
Total & 63 & 222,52 & 19,70 & & \\
\hline
\end{tabular}

The results reported in Table 3 point out that the age of the participant does not create a significant difference in critical thinking disposition, which is supportive of the hypothesis of the study. The mean score of the 21 and over age group $(\bar{X}=230,88)$ is higher than that of the 18-year-old participants $(\bar{X}=223,87), 20$ year olds $(\bar{X}=219,90)$, and 19 year olds $(\overline{\mathrm{X}}=217,04)$, but the difference is not significant at the level of $\mathrm{p}<.05$.

The Third Sub-Hypothesis: Findings Regarding Pretest Mean Scores of Groups

The third hypothesis stated that there would be no significant difference between the pretest mean scores of experiment, placebo, and control groups, and one-way Anova statistics were employed to test this claim. Analysis was carried out after the assumption of homogeneity of variances was met. The findings are given in Table 4.

\section{Table 4.}

One-Way Anova Regarding the Difference between Critical Thinking Pretest Scores of Experiment, Placebo, and Control Groups

\begin{tabular}{lccccc}
\hline & $N$ & $\bar{X}$ & $S S$ & $F$ & $P$ \\
\hline Experiment & 21 & 221,88 & 21,37 & & \\
Placebo & 21 & 223,25 & 20,72 & & \\
Control & 21 & 222,43 & 17,77 & .025 & .975 \\
Total & 63 & 222,52 & 19,70 & & \\
\hline
\end{tabular}

When Table 4 is examined, critical thinking mean score of the placebo group $(\bar{X}=223,25)$ is observed to be higher than that of the control group $(\bar{X}=222,43)$ and that of the experiment group $(\bar{X}=221,88)$. However, the results of variance analysis demonstrate that the difference between the three groups in terms of critical thinking pretest scores is not significant at the level of $\mathrm{p}<.05$, in parallel to the hypothesis. 
The Fourth Sub-Hypothesis: Findings Regarding Posttest Mean Scores of Groups

In the last hypothesis, it was predicted that there would be a significant difference between the posttest scores of experiment, placebo, and control groups in favor of the experiment and placebo groups. Table 5, which was prepared concerning this hypothesis, shows the mean, standard deviation, and standard error values regarding the total scores of all three groups.

Table 5.

Mean, Standard Deviation, and Standard Error Values Regarding Experiment, Placebo, and Control Groups

\begin{tabular}{lllclc}
\hline & & $N$ & $\bar{X}$ & $S S$ & $S H$ \\
\hline Experiment & Pretest & 21 & 221,88 & 21,37 & \multirow{2}{*}{ C,65 } \\
& Posttest & 21 & 223,67 & 19,77 & \\
Placebo & Pretest & 21 & 223,25 & 20,72 & \multirow{2}{*}{ Cos,65 } \\
& Posttest & 21 & 234,81 & 25,52 & \\
& Pretest & 21 & 222,43 & 17,77 & \multirow{2}{*}{ Control } \\
& Posttest & 21 & 223,40 & 15,70 & \\
\hline
\end{tabular}

As Table 5 indicates, there is an increase in the posttest mean scores of all three of experiment, placebo, and control groups. When the groups are sorted by the amount of increase, the placebo group takes the first place with an increase of 12 points from $(\bar{X}=223,25)$ to $(\bar{X}=234,81)$. The placebo group is followed by the experiment group with an increase of nearly 2 points from $(\bar{X}=221,88)$ to $(\bar{X}=223,67)$ and lastly, the control group with an increase of 1 point from $(\bar{X}=222,43)$ to $(\bar{X}=223,40)$.

Covariance (Ancova) analysis was carried out in order to determine the significance of the mentioned difference. The results regarding the analysis are summarized in Table 6. 
Table 6 .

Posttest Covariance Analysis of Experiment, Placebo, and Control Groups

\begin{tabular}{llllll}
\hline Origin of Variance & Sum of Squares (SS) & $d f$ & Mean Square & $F$ & $p$ \\
\hline Pretest (Mean Value) & 20,99 & 1 & 20,99 & .05 & .83 \\
Group (Main Effect) & 1788,38 & 2 & 894,19 & 1.96 & .14 \\
Error & 26811,2 & 59 & 454,42 & & \\
Total & 32834,34 & 63 & & & \\
\hline
\end{tabular}

There are significant differences between the posttest scores of experiment, placebo, and control groups in favor of the experiment and placebo groups. According to the covariance analysis in Table 6, the main group effect is seen to be insignificant based on the posttest corrected scores of the groups $(F=1.96 ; p=.14)$. This finding can be interpreted as that the experimental program and placebo effect do not make a significant difference compared to the control group in improving the critical thinking skills of students.

\section{Discussion and Conclusion}

\section{Gender and Critical Thinking}

It was found in the first sub-hypothesis that the critical thinking dispositions of students did not vary based on gender. The other studies in the literature were also supportive of this idea. Korkmaz (2009a) and Emir (2012) who conducted studies on critical thinking skills of students in the faculties of Education, Karasakaloglu, Saracaloglu and Yilmaz Ozelci (2012) who investigated the reading strategies and critical thinking attitudes of Turkish candidate teachers concluded that there was no significant difference between critical thinking scores based on gender, but there were some differences in sub-dimensions. This same conclusion was reached by Piji Kucuk and Uzun (2012) who studied critical thinking dispositions of candidate music teachers, Karadeniz and Gursoy (2014) who examined the effects of methods of poet analysis upon critical thinking processes of students through an experimental study, and Coskun (2013) who compared the students of education of religion and ethics to those of theology. Similarly, Hamurcu and others (2005) came up with some differences based on gender in the sub-dimensions of the research they carried out on science and primary school teachers. In their study, Alkin Sahin, Tunca and Ulubey (2014) and Kartal (2012) concluded that there was a significant difference based on gender in terms of total scores. The fact that there is no significant difference based on gender in most of the studies is consistent with the theoretical basis, whereas the contrary results were reached by others can be associated with the sampling choice. The findings retrieved are consistent with the literature in this sense. 


\section{Age and Critical Thinking}

The basis of our second hypothesis is that critical thinking is not a phenomenon improved by age but rather by the progress made in education. There are a large number of studies supporting this suggestion in the literature. Korkmaz (2009a) found that critical thinking dispositions of students at the faculty of education varied significantly based on the class level and Kartal (2012) reached the same conclusion for teacher candidates in science for primary schools. Piji, Kucuk and Uzun (2012) studying the critical thinking dispositions of music teacher candidates and Karasakaloglu, Saracaloglu and Yilmaz Ozelci (2012) who investigated reading strategies and critical thinking attitudes of Turkish teacher candidates also came up with findings supportive of this idea. If the teaching profession is regarded as a stage in itself in terms of education, the findings of Korkmaz (2009b), Ulucan and others (2011), indicating that duration of teachers' service is not a determining factor in their critical thinking, can also serve as a source for this idea. In our study, it was found that critical thinking dispositions of students did not vary by age. All of the participants of various ages study in the same class and as they share the same class environment, there was no significant difference between them in terms of critical thinking. This conclusion is consistent with the literature with reference to the above mentioned studies.

\section{Differences in Critical Thinking Levels}

In the third hypothesis, it was predicted that the pretest mean scores of the students in sample groups, to which they were assigned according to the last digits of their student numbers, would not differ significantly. The analyses carried on to test this claim demonstrated no significant difference, supporting the hypothesis. The result attained indicates that the grouping did not affect the outcome as a noisy variable during the application. Consequently, it can be said that the necessary assumption, which is the insignificance of the grouping effect, was met in order to carry out the analyses regarding the last hypothesis that "there is a significant difference between the posttest scores of critical thinking levels of students in favor of experiment and placebo groups."

\section{Comparison of Critical Thinking Training and Placebo Effect}

Analyses carried out to test the last hypothesis and data derived from the experiment demonstrate a positive improvement in the critical thinking disposition mean scores of the experiment group on which the planned program was applied; of the placebo group, which was maintained by some encouraging statements without applying any special procedures; and of the control group. However, that improvement is not a significant one statistically. The most important change in terms of amount of improvement took place in the placebo group; next in the experimental group; and lastly, in the control group. This finding is also supported with the findings of Adam and Manson (2014). There is no need to call on difficult methods in critical thinking; the students can be oriented toward critical thinking merely by using the method of thinking over pseudoscience scenarios. Seferoglu and Akbiyik (2006) argue that in critical thinking training it is important to create an 
atmosphere in which the students can feel secure, to place extra emphasis on asking questions, and to give the students the opportunity to consider their own thinking processes. In this context, the fact that the placebo group made further improvement is consistent with the literature.

In this study, it is an important finding that merely the effort to create a positive atmosphere in the placebo group induced a higher level of improvement than in the experiment group where activity and practice were made possible. Furthermore, another important step in the improvement of critical thinking is to train the students to observe the factors orienting them to take the initiative to apply critical thinking (Cohen, 1993, p.241). It takes a long time for this observation to become a part of the process. This study was relatively short in terms of its duration, which may account for not attaining the expected effect. Kong (2015), in his study where the peripheries of learning were extended and an interactive method of teaching was used (2015), emphasized the importance of duration. He stated that even at the end of his threeyear study, students still needed more time to improve their capacity of deduction, explanation and evaluation. Furthermore, application of scales per se is regarded as insufficient in assessing critical thinking and it is recommended to apply various methods of measurement and to use random sampling (Polat, 2015). In this sense, the facts that this study applied a singular method of measurement and the study group did not enable random sampling may have affected the result.

Another important finding in the literature is that there is a relation between the educational beliefs of the students and their critical thinking disposition (Alkin Sahin, Tunca and Ulubey, 2014). This claim gives rise to the question of whether beliefs are noisy variables for researches. Tok and Sevinc (2010) similarly underlined a long and detailed period of education of critical thinking skills and the importance of enhancing critical thinking education by means of supportive activities, and recommend fighting against faulty affective entry behaviors of students, such as saying "I can't." In this research, no study for the purpose of defining the educational beliefs or affective entry behaviors of the students was carried out, which may have had an effect on the results.

In addition, the critical thinking skills program applied in the study was developed by researchers and, thus, the absence of any findings as to the validity or the effect of the program in the literature is an important limitation of the study. Carrying on the same study using a critical thinking program whose effect has been established may produce more valid results on the contrastive placebo effect.

In light of all findings, the following suggestions are made for future studies on critical thinking: 1) Analyze the affective entry behaviors and educational beliefs of the groups to be researched during the assignment of members to the groups 2) Employ mixed methods of measurement in the assessment of critical thinking 3) Plan the study for a longer duration of time (both in terms of time weekly and total time period) and with an educational program whose effect has previously been established 4) Carry out the same study again on students studying in other 
departments. Furthermore, including the out of school time in the study may be helpful for a training program of critical thinking.

\section{References}

Adam, A., \& Manson, T. (2014). Using a pseudoscience activity to teach critical thinking. Teaching of Psychology, 41(2), 130-134.

Aksoy, B. (2003). Problem cozme yonteminin cevre egitiminde uygulanmasi [Problem solving method and applications to environmental education]. Pamukkale Universitesi Egitim Bilimleri Dergisi, 2(14), 83-98.

Alkin Sahin, S., Tunca, N., \& Ulubey , O. (2014). The relationship between pre-service teachers' educational beliefs and their critical thinking tendencies. Elementary Education Online, 13(4), 1473-1492.

Arsal, Z. (2015). The effects of microteaching on the critical thinking dispositions of pre-service teachers. Australian Journal of Teacher Education, 40(3), 140-153.

Aybek, B. (2007). Konu ve beceri temelli elestirel dusunme ogretiminin ogretmen adaylarinin elestirel dusunme egilimi ve duzeylerine etkisi [Effect of skill and content based critical thinking training on teacher candidades critical thinking dispositions and extend]. Cukurova Universitesi Sosyal Bilimler Enstitusu Dergisi, 16(2), 43-60.

Bagci, H., Sahbaz, N. K. (2012). Turkce ogretmeni adaylarinin elestirel dusunme becerileri uzerine bir degerlendirme [An analysis of the Turkish teacher candidates]. Mersin Universitesi Egitim Fakultesi Dergisi, 8(1), 1-12

Bayat, N. (2014). The relationship between prospective teachers' levels of critical thinking and their success in academic writing. Education and Science, 39(173), 155169.

Cohen, M. (1993). Making critical thinking a classroom reality. Political Science and Politics, 26(2), 241-244.

Coskun, M. (2013). Din kulturu ve ahlak bilgisi ogretmen adaylarinin elestirel dusunme egilimleri [Critical thinking level and dispositions of pre-service teachers of religious culture and ethics knowledge] (Ilahiyat- Egitim DKAB karsilastirmasi). Ataturk Universitesi Sosyal Bilimler Enstitusu Dergisi, 17(1), 143162.

Emir, S. (2012). Egitim fakultesi ogrencilerinin elestirel dusunme egilimleri [Critical dispositions of education faculty students]. Hasan Ali Yucel Egitim Fakultesi Dergisi, 17, 34-57.

Hamurcu, H., Gunay, Y., \& Akamca, G. (2005). Fen bilgisi ve sinif ogretmenligi anabilim dali ogrencilerinin elestirel dusunme egilimi profilleri [Profiles of 
critical thinking dispositions of science and class teacher candidates]. Eurasian Journal of Educational Research, 20, 147-157.

Karadeniz, A., \& Gursoy, U. (2014). Modern metin cozumleme yontemlerinin elestirel dusunme, yaratici dusunme ve problem cozme becerilerine etkisi [The effect of modern text analysis on critical thinking, creative thinking and problem solving skills]. Ahi Evran Universitesi Kirsehir Egitim Fakultesi Dergisi (KEFAD), 15(2), 99-117.

Karakas, E. (2014). Siniftan cevaplarla cikiyoruz! [Leaving the classroom with questions in mind]. Star Gazete. Retrieved 05 May 2015, from http://haber.star.com.tr/yazar/siniftan-cevaplarla-cikiyoruz/yazi-910186.

Karasakaloglu, N., Saracaloglu, S. \& Yilmaz Ozelci, S. (2012). Turkce ogretmeni adaylarinin okuma stratejileri, elestirel dusunme tutumlari ve ust bilissel yeterlilikleri [Turkish prospective teachers' reading strategies, critical thinking attitudes and metacognitive conpetencies]. Ahi Evran Universitesi Kirsehir Egitim Fakultesi Dergisi, 13(1), 207-221.

Kartal, T. (2012) Ilkogretim fen bilgisi ogretmen adaylarinin elestirel dusunme egilimlerinin incelenmesi [An investigation of primary science teachers' critical thinking dispositions]. Ahi Evran Universitesi Kirsehir Egitim Fakultesi Dergisi, 13(2), 279-297.

Kong, S. C. (2015). An experience of a three-year study on the development of critical thinking skills in flipped secondary classrooms with pedagogical and technological support. Computers E Education(89), 16-31.

Korkmaz, O. (2009a). Egitim fakultelerinin ogrencilerinin elestirel dusunme egilim ve duzeylerine etkisi [The influence of education faculties on students' critical thinking level and disposition]. Turk Egitim Bilimleri Dergisi, 7(4), 879-902.

Korkmaz, O. (2009b). Ogretmenlerin elestirel dusunme egilim ve duzeyleri [Teachers' critical thinking level and dispositions]. Ahi Evran Universitesi Kirsehir Egitim Fakultesi Dergisi (KEFAD), 10(1), 1-13.

Kokdemir, D. (2003). Belirsizlik durumlarinda karar verme ve problem cozme [Problem solving and decision making under uncertainty]. (Doktora Tezi), Ankara Universitesi, Ankara.

Piji Kucuk, D., Uzun, Y. B. (2013). Muzik Ogretmeni Adaylarinin Elestirel Dusunme Egilimleri [Critical thinking dispositions of music teacher candidates]. Ahi Evran Universitesi Kirsehir Egitim Fakultesi Dergisi, 14(1), 327-345.

Polat, S. (2015). Content analysis of the studies in turkey on the ability of chritical thinking. Educational Sciences: Theory \& Practice, 15(3), 659-670. 
Rezaei Kargar, F., Ajilchi, B., Kalantar Choreishi, M., \& Zohoori Zangene, Z. (2013). The effect of teaching critical and creative thinking skills on the locus of control and psychological well-being in adolescents. Procedia - Social and Behavioral Sciences, 82, 51-56.

Seferoglu, S., \& Akbiyik, C. (2006). Elestirel dusunme ve ogretimi [Teaching critical thinking]. Hacettepe Egitim Fakultesi Dergisi, 30, 193-200.

Sengul, C., \& Ustundag, T. (2009). Fizik ogretmenlerinin elestirel dusunme egilimi duzeyleri ve duzenledikleri etkinliklerde elestirel dusunmenin yeri [Critical thinking disposition levels of physics teachers and state of critical thinking in classroom activities]. Hacettepe Universitesi Egitim Fakultesi Dergisi, 36, 237-248.

Tok, E., Sevinc, M. (2010). Dusunme becerileri egitiminin elestirel dusunme ve problem cozme becerilerine etkisi [The effect of thinking skills education on the critical thinking and problem solving skills of preschool teacher candidates]. Pamukkale Universitesi Egitim Fakultesi Dergisi, 27, 67-82.

Tumkaya, Songul. (2011). Fen bilimleri ogrencilerinin elestirel dusunme egilimleri ve ogrenme stillerinin incelenmesi [Comparison of college science major students' learning styles and critical thinking disposition]. Ahi Evran Universitesi Egitim Fakultesi Dergisi, 12(3), 215-234.

Ulucan, H., Turkcapar, U., \& Cihan, B. (2011). Beden egitimi ogretmenlerinin elestirel dusunme egilim ve duzeyleri [Critical thinking disposition and level of physical education teachers]. Ataturk Journal of Physical Education and Sport Sciences (Atabesbd), 13(2), 42-52.

\section{Öğretmen Eğitiminde Eleştirel Düşünme Eğitimi ve Plasebo Etkisi: Yarı Deneysel Bir Çalışma}

Atif:

Demirbag, B., Unisen, A., \& Yesilyurt, A. (2016) Training of critical thinking skills in teacher candidates and placebo effect: A quasi experimental study. Eurasian Journal of Educational Research, 63, 375-392 http://dx.doi.org/ 10.14689/ejer.2016.63.21

\section{Özet}

Problem Durumu: Son yıllarda eleştirel düşünme becerilerinin sergilenmesiyle ilgili çok sayıda çalışma bulunduğu, ancak bu çalışmaların ağırlıkla eleştirel düşünme becerileriyle ilgili değişkenler üzerine odaklandığı görülmektedir. Bunların yanı sıra eleştirel düşünme becerisinin sergilenmesini belirli gruplar üzerinde tarama ve ilişkisel olarak araştıran çalışmalar da alana önemli katkılar sağlamaktadır. Her iki 
grupta yer alan çalışmalar ağırlıkla üniversite öğrencileri ve özellikle de öğretmen adayları evren ve örneklemlerinde yapılmıştır. Alan yazının uygulamalı çalışmalar açısından oldukça zayıf olduğu gözlenmektedir. Eleştirel düşünme becerilerinin sergilenmesi sürecini derinlemesine anlamak için ampirik araştırmaların sayıca artması gerekliliği ortadadır.

Araştırmanın Amacl: $\mathrm{Bu}$ çalışma üniversite öğrencilerinin eleştirel düşünme becerilerinin geliştirilmesinde deneysel bir program ve plasebo etkisini karşılaştırmalı olarak araştırmayı amaçlamaktadır. Araştırmada;

a. Katılımcıların eleştirel düşünme becerilerini sergilemede cinsiyet açısından istatistiksel anlamlı fark yoktur,

b. Katılımcıların eleştirel düşünme becerilerini sergilemede yaş açısından istatistiksel anlamlı fark yoktur,

c. Deney, plasebo ve kontrol gruplarının ön-test puan ortalamaları arasında istatistiksel anlamlı fark yoktur,

d. Ön-test puanları kontrol altına alındığında, deney, plasebo ve kontrol gruplarının son-test puanları arasında deney ve plasebo grupları lehine istatistiksel anlamlı fark vardır, hipotezleri test edilmiştir.

Araştırmanın Yöntemi: Adıyaman üniversitesi eğitim fakültesi Arapça öğretmenliği bölümü öğrencileri arasından 63 katılımcı her biri 21 kişiden oluşan deney, kontrol ve plasebo gruplarına atanmışlardır. Gruplara katılımcı atanması zaten var olan sınıf düzenlerinden yararlanılarak yapıldığından çalışma yarı deneysel metotta yürütülmüştür. Deney grubunda araştırmacılar tarafından hazırlanan 8 haftalık bir program, placebo grubunda öğrencilere eleştirel düşünme ile ilgili motive edici pozitif bir ortam ve eleştirel düşünmenin gerekliliğinden bahsedilirken kontrol grubunda (eleştirel düşünmeye yönelik) herhangi bir etkinlik düzenlenmemiştir. Katılımcıların eleştirel düşünme becerilerini ölçmede Türkçe'ye Kökdemir (2003) tarafından uyarlanan CCTDI (Kaliforniya Eleştirel Düşünme Eğilimi Ölçeği) kullanılmıştır. Verilerin analizinde SPSS 20.0 paket programı kullanılmıştır. Verilerin analizinde yaş değiş̧keni için varyans analizi, cinsiyet değişkeni için bağımsız gruplar $t$-testi ve deney, kontrol ve plasebo grupları üzerinde çalışmanın etkililiğini saptamak için ancova testlerine başvurulmuştur.

Araştırmanın Bulguları: Ancova, testin varsayımını karşılamak için üç grubun ötesi puanları arasında anlamlı bir farklılık olup olmadığı tek yönlü anova ile araştırılır, varsayımının karşılandığı sonucuna ulaşılmıştır. Bağımsız gruplar $t$-testi sonuçları kadın katılımcılar $(\bar{X}=222,11)$ ve erkek katılımcılar $(\bar{X}=223,83)$ arasında eleştirel düşünme becerilerini sergilemeleri açısından istatistiksel olarak farklılaşmadı̆̆ını göstermiştir. Katılımcıların yaş değişkenine göre yapılan varyans analizine göre 21 ve üstü yaş grubundaki katılımcıların aritmetik ortalamaları sırasıyla $(\bar{X}=230,88) 18$ yaşındaki $(\bar{X}=223,87), 20$ yaşındaki $(\bar{X}=219,90)$ ve 19 yaşındaki $(\bar{X}=217,04)$ katılımcıların aritmetik ortalamalarından daha yüksek bulunmuştur. Ancak bu farkın araştırmanın ikinci hipotezini destekleyerek $\mathrm{p}<.05$ düzeyinde istatistiksel olarak anlamlı olmadığı ortaya çıkmıştır. 
Üçüncü hipotezle ilgili olarak, plasebo grubunun aritmetik ortalaması $(\bar{X}=223,25)$ kontrol $(\overline{\mathrm{X}}=222,43)$ ve deney gruplarından $(\overline{\mathrm{X}}=221,88)$ daha yüksek bulunmuştur. Ancak her üç grupta da son-testte elde edilen puanların ön-test puanlarıyla karşılaştırılmasıyla ölçülen farkın istatistiksel olarak anlamlı olmadığı görülmektedir.

Grupların aritmetik ortalamalarındaki mutlak artış dikkate alındığında plasebo grubunun $(\overline{\mathrm{X}}=223,25)^{\prime}$ ten $(\overline{\mathrm{X}}=234,81)^{\prime}$ e yükselerek 12 puanlık bir artışla ilk sıra yer aldığı görülmektedir. Plasebo grubunu aritmetik ortalamada 2 puanlık artışla $(\bar{X}=221,88)^{\prime}$ den $(\bar{X}=223,67)^{\prime}$ e yükselen deney grubu izlemektedir. Kontrol grubu öntest puanı $(\overline{\mathrm{X}}=221,88)$ ile son-test puanı $(\overline{\mathrm{X}}=223,40)$ arasında 1 puanlık fark oluşturarak son sırada kalmıştır.

Grup etkisinin, düzeltilmiş son-test puanları üzerindeki etkisinin istatistiksel olarak anlamlı olmadığ1 görülmüştür $(\mathrm{F}=1.96 ; \mathrm{p}=.14)$. Bu bulgu deneysel program ve plasebo etkisinin kontrol grubuyla karşılaştırıldığında katılımcıların eleştirel düşünme becerilerini geliştirmede anlamlı fark oluşturmadığı şeklinde yorumlanabilir.

Araştırmanın Sonuç ve Önerileri: Yaş değişkeni için uygulanan varyans analizi sonuçları gruplar arasında istatistiksel açıdan anlamlı bir farklılık olmadı̆̆ını göstermiştir. Çalışmanın bulguları, aynı eğitim kademesine devam öğrenciler ile aynı mesleği yapan kişilerin eleştirel düşünme becerilerinin yaş değişkenine göre farklılaşmadığını gösteren çalışmalarla aynı doğrultudadır.

Cinsiyet, eleştirel düşünme becerilerinin sergilenmesi toplam puanlarında bir bütün olarak değil de alt-boyutlarda anlamlı fark oluşturabilmektedir. Bu çalışmada da cinsiyetin eleştirel düşünme becerilerinin geliştirilmesine yönelik bir programda anlamlı bir değişken olmadığı görüldü.

Çalışmadaki grup ortalama puanlarının sırasıyla plasebo, deney ve kontrol grupları şeklinde sıralanması eleştirel düşünme eğitiminde uygulanan program kadar programın uygulandığı duyuşsal çevrenin de etkili olduğunu göstermektedir. Araştırmada, sadece plasebo grubundaki eleştirel düşünme için oluşturulan olumlu iklimin, deney grubuyla karşılaştırıldığında eleştirel düşünme becerisine olumlu katkısının göreceli olarak daha yüksek seviyede olduğunun tespiti önemli bir bulgu olarak değerlendirilmektedir.

Bir programın kazanımlarının katılımcıların hayatına yansımaları zaman alabilir. Buradan hareketle uygulanan programın eleştirel düşünme becerilerini katılımcıların karakteristik özelliklerine katacak yeterlikte olmadığı, programın daha uzun bir süreye yayılması gerektiği söylenebilir.

Uygulanan eleştirel düşünme becerilerini geliştirme programının araştırmacılar tarafından tasarlanmış olması, dolayısıyla alan yazında programla ilgili geçerlik veya programın etkinliğine ilişkin herhangi bir bulgunun olmayışı çalışmanın önemli bir sınırlığı olarak öne çıkmaktadır. Aynı çalışmayı sonuçları bilinen bir programla uygulamak plasebo etkisiyle ilgili daha geçerli sonuçlar verecektir. 
Eleştirel düşünme becerileriyle ilgili, bu çalışmanın bulguları doğrultusunda aşağıdaki öneriler geliştirilmiştir: 1) Gruplara atamada bireylerin duyuşsal giriş davranışları ve eğitimsel inançlarının analiz edilmesi 2) Eleştirel düşünme becerilerinin ölçülmesinde karma yönteme başvurulması 3) Daha uzun süreli programlar tasarlama (hem dönem hem haftalık süre olarak) 4) Çalışmayı farklı bölüm öğrencileri ile tekrarlamak.

Anahtar Kelimeler: Düşünme, eleştirel düşünme, plasebo etkisi, öğretmen adayları. 